Jurnal Pendidikan Bahasa dan Sastra Indonesia

\title{
PENINGKATAN KETERAMPILAN MEMBACA TEKS KLASIFIKASI MENGGUNAKAN METODE SQ3R DENGAN MEDIA GAMBAR
}

\section{Eko Widianto ${ }^{\bowtie}$ dan Subyantoro}

Jurusan Bahasa dan Sastra Indonesia, Fakultas Bahasa dan Seni, Universitas Negeri Semarang, Indonesia

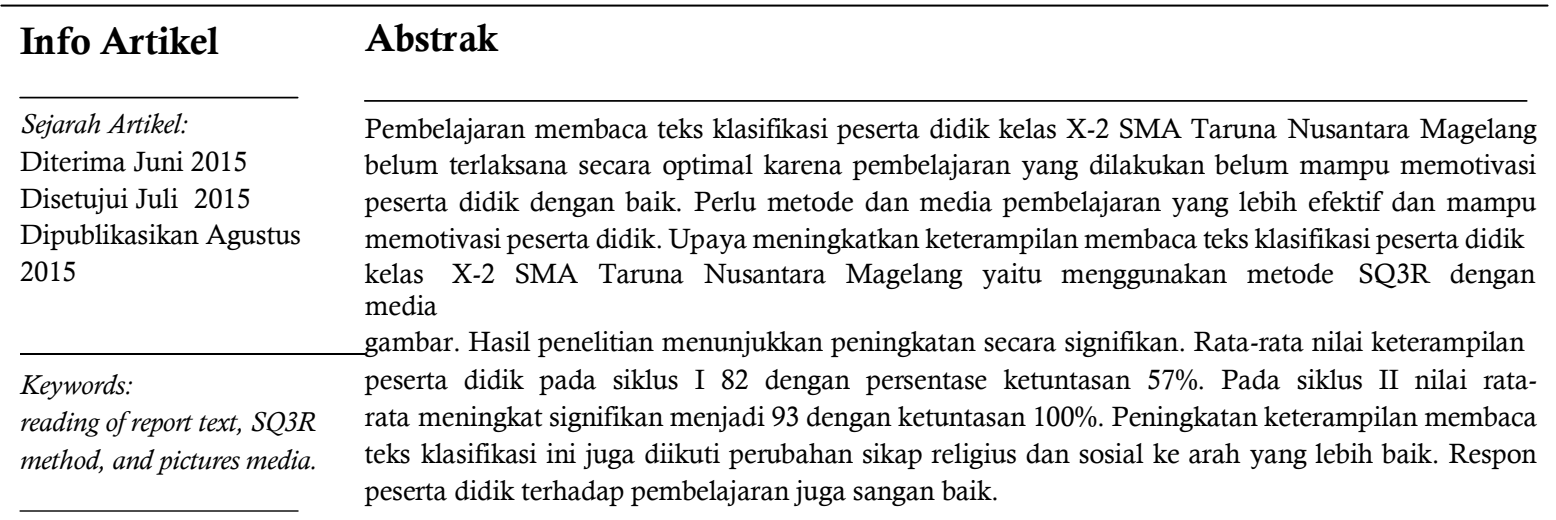

\begin{abstract}
Learning of report text reading in SMA Taruna Nusantara Magelang is not performing well cause the students haven't been motivated by the lesson. They need a method and media on this learning which can motivate the students. The effort to improve the reading skill of report text of SMA Taruna Nusantara Magelang Students for the first class is using a SQ3R methode and pictures media. The result of this study indicates a significant improvement. The average score of students reading in the first cycle increases from 82 to 93 on the second cycle. The completeness percentage also increases from $57 \%$ to $100 \%$. The reading skill improvement is also followed by better learning process, religous attitude, and social attitudes than before.
\end{abstract}

(C) 2015 Universitas Negeri Semarang

\footnotetext{
Alamat korespondensi:

Gedung B1 Lantai 1 FBS Unnes

Kampus Sekaran, Gunungpati, Semarang, 50229

E-mail:_widiantoeko@yahoo.co.id
}

ISSN 2252-6722 


\section{PENDAHULUAN}

Membaca menurut Haryadi (2010:77) merupakan interaksi antara pembaca dan penulis. Interaksi tersebut tidak langsung, namun bersifat komunikatif. Komunikasi antara pembaca dan penulis akan semakin baik jika pembaca mempunyai kemampuan yang lebih baik. Pembaca hanya dapat berkomunikasi dengan karya tulis yang digunakan oleh pengarang sebagai media untuk menyampaikan gagasan, perasaan, dan pengalamannya. Dengan demikian pembaca harus mampu menyusun pengertian-pengertian yang tertuang dalam kalimat-kalimat yang disajikan oleh pengarang sesuai dengan konsep yang terdapat pada diri pembaca.

Wulan (2010) dalam jurnal penelitiannya mengungkapkan bahwa membaca adalah salah satu faktor yang penting dalam kehidupan masyarakat modern. Kemampuan membaca menjadi kebutuhan karena penyebaran informasi dan pesan-pesan dalam dunia modern ini disajikan dalam bentuk tertulis, dan hanya dapat diperoleh melalui membaca. Apabila seseorang tidak mampu membaca sehingga tidak memahami suatu petunjuk atau pengumuman yang tertulis, maka orang tersebut akan ketinggalan, salah jalan, atau tidak dapat menyesuaikan diri dengan lingkungannya.

Berdasarkan data yang peneliti temukan melalui wawancara terhadap guru mata pelajaran bahasa Indonesia kelas $\mathrm{X}$ di SMA Taruna Nusantara Magelang, penguasaan keterampilan membaca teks klasifikasi peserta didik kelas X-2 SMA Taruna Nusantara Magelang masih belum optimal. Terbukti dari 24 peserta didik, hanya delapan peserta didik yang mampu mencapai kriteria ketuntasan minimal dengan skor 75 . Hal ini menunjukkan bahwa kompetensi pengetahuan dan keterampilan peserta didik dalam membaca teks klasifikasi belum optimal. Hasil pengamatan guru terhadap sikap peserta didik juga belum menunjukkan karakter religius dan sosial secara maksimal.

Penilaian guru terhadap pengetahuan dan keterampilan membaca teks klasifikasi peserta didik juga belum sepenuhnya memuaskan.
Hanya delapan dari 24 peserta didik yang mampu mencapai ketuntasan minimal. Peserta didik yang belum mencapai kriteria minimal umumnya memiliki beberapa permasalahan terkait pengetahuan dan keterampilan dalam membaca. Permasalahan tersebut antara lain; 1) peserta didik kurang terampil dalam membaca sebuah teks, 2) peserta didik masih kurang memerhatikan pokok-pokok bacaan, 3) peserta didik cepat merasa jenuh dengan teks bacaan yang panjang, dan 4) peserta didik masih kurang teliti dalam membaca, 5) setelah membaca, peserta didik kesulitan dalam menyimpulkan bacaan, dan 6) pembelajaran dirasakan monoton dan membosankan oleh peserta didik karena metode serta media pembelajaran kurang digunakan secara optimal.

Permasalahan-permasalaan tersebut menjadi tantangan bagi guru mata pelajaran bahasa Indonesia untuk menciptakan suasana baru dalam pembelajaran membaca. Suasana dan cara baru itu diharapkan mampu meningkatkan semangat belajar dan keterampilan membaca siswa. Hal ini memberi indikasi bahwa metode dalam membaca menjadi sangat penting dalam kegiatan pembelajaran di kelas X SMA Taruna Nusantara Magelang. Metode ini berfungsi mengangkat semangat peserta didik dalam pembelajaran membaca. Selain itu, metode dalam membaca diharapkan mampu mengefektifkan pembelajaran keterampilan membaca di dalam kelas. Melihat permasalahan tersebut, peneliti menawarkan solusi berupa penggunaan metode SQ3R dan media gambar dalam pembelajaran membaca.

Salah satu metode dalam keterampilan membaca adalah metode SQ3R. Metode ini mengarahkan pembaca melakukan Survey, Question, Reading, Recite, dan Review dalam kegiatan membaca. Tahapan-tahapan tersebut akan memudahkan pembaca dalam menemukan pokok bacaan dan menyimpulkan isi bacaan yang telah dibaca (Haryadi 2010).

Fakta di lapangan juga menunjukkan bahwa media pembelajaran yang digunakan dalam pembelajaran membaca kurang optimal. Hal ini menyebabkan peserta didik sering dihinggapi rasa jenuh dalam kegiatan 
pembelajaran. Selain metode SQ3R, peserta didik akan dimudahkan dengan media gambar untuk mengulas kembali bacaan. Isi tayangan gambar disesuaikan dengan teks yang dibaca oleh peserta didik. Jadi, setelah peserta didik membaca sebuah bacaan dengan langkahlangkah sesuai metode SQ3R, mereka mengulas kembali isi bacaan dengan acuan sebuah gambar.

Penelitian ini dilakukan dengan mendeskripsikan proses pembelajaran. Penelitian ini juga mengungkapkan hasil peningkatan pengetahuan dan keterampilan peserta didik dalam membaca teks klasifikasi. Selain itu, penelitian ini juga mendeskripsikan perubahan sikap religius dan sosial peserta didik dalam mengikuti pembelajaran membaca teks klasifikasi menggunakan metode SQ3R dengan media gambar.

\section{LANDASAN TEORETIS}

Secara sederhana Abidin (2012) memberikan penjelasan tentang membaca. Menurut Abidin (2012:147) membaca secara sederhana dikaitkan sebagai proses membunyikan lambang bahasa tulis. Dalam pengertian ini, membaca sering disebut sebagai membaca nyaring atau membaca permulaan. Membaca juga dapat dikatakan sebagai proses untuk mendapatkan informasi yang terkandung dalam teks bacaan untuk beroleh pemahaman atas bacaan tersebut. Membaca seperti ini dapat dikatakan sebagai membaca pemahaman. Membaca merupakan aktivitas yang dilakukan guna mengkritisi bacaan, maka disebut membaca kritis. Selain ketiga definisi tersebut, membaca juga dikatakan sebagai proses memperoleh informasi sebagai bahan pengembangan produk kreatif pascabaca. Membaca seperti ini dapat dikatakan sebagai membaca kreatif. Berdasarkan beberapa pengertian membaca tersebut jelas bahwa membaca pada prinsipnya dapat didefinisikan berdasarkan berbagai sudut pandang.

Tujuan membaca menurut Rahim (2008) antara lain; 1) kesenangan; 2) menyempurnakan membaca nyaring; 3) menggunakan strategi tertentu; 4) memperbarui suatu pengetahuan tentang topik; 5) mengaitkan informasi baru dengan informasi yang telah diketahui; 6) memperoleh informasi untuk laporan lisan atau tertulis; 7) mengonfirmasi atau menolak prediksi; 8) menampilkan suatu eksperimen atau mengaplikasikan informasi yang diperoleh dari suatu teks dalam beberapa cara lain dan mempelajari tentang struktur teks; dan 9) menjawab pertanyaan-pertanyaan yang spesifik.

Berdasarkan pendapat mengenai keterampilan membaca tersebut, dapat diambil sebuah simpulan. Membaca merupakan keterampilan berbahasa yang bersifat reseptif dan sangat penting bagikehidupan. Artinya membaca membawa seseorangmenerima informasi dari kegiatan tersebut. Informasiinformasi tersebut adalah informasi yang berguna dan penting bagi seseorang. Melalui membaca seseorang berinteraksi dengan penulis untuk memperoleh informasi. Keterampilan membaca tidak dapat didapatkan secara instan oleh seseorang. Seseorang harus melewati tahap demi tahap dalam meningkatkan keterampilan membacanya. Membaca juga dapat dilakukan dengan bersuara maupun tidak. Bergantung pada tujuan dan materi bacaan yang tengah dihadapai oleh pembaca.

\section{Teks Klasifikasi}

Kemdikbud (2013) menjelaskan bahwa teks laporan juga sering disebut teks klasifikasi. Teks ini mengutamakan hubungan antara kelas dan sub-subkelas atau anggota-anggota kelas yang ada. Struktur teksnya adalah pernyataan umum/klasifikasi anggota/aspek yang dilaporkan. Teks laporan juga disebut teks klasifikasi karena teks tersebut memuat klasifikasi mengenai jenis-jenis sesuatu berdasarkan kriteria tertentu. Setelah menyelesaikan pelajaran ini, kalian diharapkan dapat membangun teks laporan yang benar.

Kosasih (2013:48) juga menjelaskan sebuah teks disebut teks laporan hasil observasi atau teks klasifikasi karena teks itu mengemukakan fakta-fakta yang diperoleh melalui pengamatan. Melalui teks tersebut, pembaca memperoleh sejumlah pengetahuan ataupun wawasan, bukan hasil imajinasi. Artinya 
teks ini bukan termasuk ke dalam teks sastra atau fiksi. Teks laporan/klasifikasi menyajikan faktafakta atau sesuatu yang sudah pasti ada/terjadi.

Berdasarkan penjabaran teks klasifikasi di atas, dapat disimpulkan bahwa teks klasifikasi merupakan teks yang melaporkan suatu hal secara global. Teks ini memiliki struktur berupa pernyataan umum dan aspek yang dilaporkan. Dalam kurikulum 2013, teks klasifikasi sangat penting untuk dipahami dengan baik oleh peserta didik pada jenjang SMA.

\section{Metode SQ3R dan Media Gambar}

Metode SQ3R merupakan proses membaca sistematik yang meliputi tahap Survey, Question, Read, Recite, dan Review. Kason (2012) dalam tesisnya menjelaskan bahwa metode SQ3R adalah "Study system that has been around for decades and is comprised of five steps: Survey, Question, Read, Recite, and Review." Pendapat tersebut menunjukkan bahwa metode SQ3R merupakan sistem belajar yang mengarahkan pembelajar pada lima langkah/tahapan. Langkah tersebut yaitu survey, question, read, recite, dan review. Langkah/tahapan tersebut yang mengondisikan pembaca lebih efektif dan efisien dalam membaca. Sebab sistem membaca menggunakan metode SQ3R mengarahkan pembaca pada tahapan yang berkesinambungan dalam membaca. Mulai dari perencanaan, sampai dengan tahap akhir dalam membaca.

Carlston (2012) juga mengungkapkan bahwa "The Survey-Question-Read-Recite-Review (SQ3R) method is perhaps one of the oldest and most widely implemented study strategies. The SQ3R method applies most readily to textbooks and formal reading assignments in which readers are required to consume main points from expository writing." Pendapat Carlston menunjukkan bahwa SQ3R merupakan salah satu strategi pembelajaran paling tua. Metode SQ3R menerapkan cara membaca menemukan pokok-pokok penting dalam bacaan. Kemudian pembaca membuat catatan-catatan penting berdasarkan sudut pandang pribadi.

Berdasarkan beberapa teori mengenai metode SQ3R di atas, hal penting dalam metode ini adalah keselarasan dan kesinambungan setiap tahapnya. Artinya, tahap dalam metode ini tidak dapat digunakan secara terpisah maupun bebas. Setiap tahapandalam metode ini harus diterapkan secara terstruktur dan terpola agar tujuan membaca dapat tercapai dengan baik. Melihat manfaat dan keefektifan metode SQ3R dalam membaca, peneliti akan menggunakan metode ini sebagai upaya peningkatan keterampilan membaca peserta didik pada jenjang SMA. Dengan metode ini, peneliti berharap keterampilan membaca peserta didik dalam penelitian ini akan meningkat.

Salah satu wujud media pembelajaran adalah gambar. Hamalik (1986:43) berpendapat bahwa gambar adalah segala sesuatu yang diwujudkan secara visual dalam bentuk dua dimensi sebagai curahan perasaan atau pikiran. Hal ini menunjukkan bahwa gambar dapat mewakili suatu ide, termasuk curahan perasaan ataupun pikiran. Pendapat ini menunjukkan bahwa dengan gambar ide-ide pengajar dalam pembelajaran yang sulit untuk dijelaskan dengan ceramah akan lebih mudah jika disajikan dengan gambar. Sebab tidak semua hal dapat dideskripsikan secara gamblang melalui penjelasan lisan.

Sadiman (2009:29) menyebutkan bahwa gambar atau foto termasuk dalam media grafis. Di antara media pendidikan, gambar atau foto merupakan media yang paling umum dipakai. Ia merupakan bahasa yang umum dan dapat dimengerti serta dinikmati di mana-mana. Sebab, seseorang dapat dengan mudah menemukan dan menyajikan gambar sebagai media pembelajaran. Gambar juga mampu mendeskripsikan dengan baik dan nyata sebuah ide atau suatu hal pada imajinasi seseorang.

Berdasarkan beberapa paparan mengenai media gambar beserta manfaat dan kelemahannya, media ini akan digunakan dalam penelitian ini. Media gambar masih sangat representatif untuk digunakan dalam pembelajaran. Selain mudah disajikan, media ini juga mampu menarik perhatian serta merangsang imajinasi peserta didik dalam pembelajaran.

\section{METODE PENELITIAN}


Penelitian ini menggunakan desain penelitian tindakan kelas. Penelitian tindakan kelas menurut Basrowi (2008:25) merupakan salah satu upaya guru atau praktisi dalam bentuk berbagai kegiatan yang dilakukan untuk memperbaiki dan atau meingkatkan mutu pembelajaran di kelas. Penelitian tindakan kelas merupakan kegiatan yang langsung berhubungan dengan tugas guru di lapangan. Singkatnya, PTK merupakan penelitian praktis yang dilakukan di kelas dan bertujuan untuk memperbaiki praktik pembelajaran yang ada.

Subjek penelitian ini adalah keterampilan membaca peserta didik kelas X SMA Taruna Nusantara Magelang. Adapun sumber data penelitian ini adalah kelas X-2 SMA Taruna Nusantara Magelang. Berdasarkan hasil wawancara dengan guru pengampu kelas X SMA Taruna Nusantara Magelang diketahui bahwa keterampilan membaca peserta didik kelas X-2 SMA Taruna Nusantara Magelang masih belum optimal. Oleh sebab itu, peneliti menentukan subjek penelitian pada kelas X-2. Kemudian peneliti berkolaborasi dengan guru menentukan metode membaca dan media pembelajaran untuk meningkatkan keterampilan membaca peserta didik kelas X-2 SMA Taruna Nusantara Magelang. Peneliti kemudian memilih metode SQ3R dan media gambar sebagai upaya meningkatkan keterampilan membaca peserta didik kelas X-2. Dengan demikian, sumber data dalam penelitian ini adalah kelas X-2 SMA Taruna Nusantara Magelang.

Data dalam penelitian ini berupa data kuantitatif dan data kualitatif. Data kuantitatif berupa hasil tes pengetahuan dan keterampilan peserta didik dalam membaca teks klasifikasi. Adapun data kualitatif diperoleh dari hasil observasi, jurnal, wawancara, dan dokumentasi. Analisis data juga dilakukan secara kuantitatif dan kualitatif. Data hasil tes pengetahuan dan keterampilan dianalisis dengan teknik analisis kuantitatif. Sementara hasil observasi, jurnal, wawancara, dan dokumentasi dianalisis secara kualitatif.

\section{HASIL PENELITIAN DAN PEMBAHASANNYA}

Setelah dilakukan penelitian keterampilan membaca teks klasifikasi menggunakan metode SQ3R dengan media gambar, keberlangsungan proses pembelajaran membaca teks klasifikasi pada peserta didik kelas X-2 SMA Taruna Nusantara Magelang semakin baik. Pada siklus I aspek pengamatan proses mengalami masih belum maksimal. Namun, pada siklus II setiap aspek pengamatan proses mengalami peningkatan. Aspek keantusiasan peserta didik dalam prosespembelajaran mengalami peningkatan 18\% dari siklus I ke siklus II. Aspek keantusiasan peserta didik dalam membaca menggunakan metode SQ3R masih dapat dipertahankan persentase ketuntasannya sebesar $100 \%$ dari siklus I. Persentase ketuntasan keefektifan dan keantusiasan peserta didik menggunakan media gambar dalam menyimpulkan bacaan juga dapat bertahan $100 \%$ pada siklus II. Adapun aspek keaktifan dan keantusiasan peserta didik dalam proses refleksi pembelajaran meningkat $35 \%$ pada siklus II. Rata-rata peningkatan persentase ketuntasan hasil pengamatan proses pembelajaran dari siklus I ke siklus II meningkat 13\%. Berikut tabel peningkatan persentase ketuntasan hasil pengamatan proses pembelajaran.

Tabel 1 Peningkatan Persentase Ketuntasan Hasil Pengamatan Proses Pembelajaran Siklus I ke Siklus II

\begin{tabular}{lllll}
\hline No. & $\begin{array}{l}\text { Aspek } \\
\text { Pengamatan }\end{array}$ & $\begin{array}{l}\text { Siklu } \\
\text { s I }\end{array}$ & $\begin{array}{l}\text { Siklu } \\
\text { s II }\end{array}$ & $\begin{array}{l}\text { Penin } \\
\text { gkata } \\
\text { n }\end{array}$ \\
\hline 1. & $\begin{array}{l}\text { keantusiasan } \\
\text { peserta didik } \\
\text { dalam proses } \\
\text { pembelajaran }\end{array}$ & $74 \%$ & $92 \%$ & $18 \%$ \\
\hline 2. & $\begin{array}{l}\text { keantusiasan } \\
\text { peserta didik } \\
\text { dalam } \\
\text { membaca }\end{array}$ & 100 & 100 & $0 \%$ \\
& $\begin{array}{l}\text { menggunakan } \\
\text { metode SQ3R }\end{array}$ & & & \\
\hline 3. & $\begin{array}{l}\text { keefektifan } \\
\text { dan }\end{array}$ & 100 & 100 & $0 \%$ \\
& $\begin{array}{l}\text { keantusiasan } \\
\text { peserta didik }\end{array}$ & $\%$ & \\
\hline
\end{tabular}




\begin{tabular}{|c|c|c|c|c|}
\hline & $\begin{array}{l}\text { menggunakan } \\
\text { media gambar } \\
\text { dalam } \\
\text { menyimpulka } \\
\text { n bacaan }\end{array}$ & & & \\
\hline 4. & $\begin{array}{l}\text { keaktifan dan } \\
\text { keantusiasan } \\
\text { peserta didik } \\
\text { dalam proses } \\
\text { refleksi } \\
\text { pembelajaran }\end{array}$ & $65 \%$ & $\begin{array}{l}100 \\
\%\end{array}$ & $35 \%$ \\
\hline $\mathrm{Ra}$ & Rata & $85 \%$ & $98 \%$ & $13 \%$ \\
\hline
\end{tabular}

Sikap religius peserta didik kelas X-2 SMA Taruna Nusantara Magelang mengalami peningkatan setelah mengikuti pembelajaran membaca teks klasifikasi menggunakan metode SQ3R dengan media gambar. Pada siklus I, persentase ketuntasan sikap religius peserta didik mencapai $83 \%$. Sementara pada siklus I, persentase ketuntasan sikap religius peserta didik meningkat menjadi 92\%. Dengan demikian, sikap religius peserta didik mengalami peningkatan 9\% dari siklus I ke siklus II. Berikut tabel yang mendeskripsikan peningkatan perubahan sikap religius peserta didik.

Tabel 2 Peningkatan Perubahan Sikap Religius pada Siklus I dan Siklus II

\begin{tabular}{|c|c|c|c|c|}
\hline No & $\begin{array}{l}\text { Aspek } \\
\text { Observasi }\end{array}$ & $\begin{array}{l}\text { Siklu } \\
\text { s I }\end{array}$ & $\begin{array}{l}\text { Siklu } \\
\text { s II }\end{array}$ & $\begin{array}{l}\text { Peningkata } \\
\mathrm{n} \\
\text { Pencapaia } \\
\mathrm{n}\end{array}$ \\
\hline 1. & $\begin{array}{l}\text { Sikap } \\
\text { religius } \\
\text { mensyuku } \\
\text { ri nikmat } \\
\text { Tuhan } \\
\text { Yang } \\
\text { Maha Esa }\end{array}$ & $83 \%$ & $92 \%$ & $9 \%$ \\
\hline
\end{tabular}

Sikap sosial peserta didik kelas X-2 SMA

Taruna Nusantara Magelang mengalami peningkatan setelah mengikuti pembelajaran membaca teks klasifikasi menggunakan metode SQ3R dengan media gambar. Pada siklus I, sikap jujur, tanggung jawab, toleransi, santun, dan semangat melampaui ketuntasan dengan persentase ketuntasan $100 \%$. Sementara sikap percaya diri dan kritis mencapai persentase ketuntasan yang masih lemah, yaitu $17 \%$. Adapun sikap kepemimpinan menjadi sikap yang berada pada persentase ketuntasan terendah sebesar $13 \%$. Namun, pada siklus II sikap sosial peserta didik mengalami peningkatan. Sikap jujur, tanggung jawab, toleransi, santun, dan semangat masih pada persentase ketuntasan $100 \%$. Sikap percaya diri mengalami peningkatan sebesar $71 \%$ dengan persentase ketuntasan $88 \%$ pada siklus II. Sikap kritis meningkat $66 \%$ dengan persentase ketuntasan $83 \%$ pada siklus II. Adapun sikap kepemimpinan meningkat 70\% dengan persentase ketuntasan $83 \%$ pada siklus II. Dengan demikian, sikap sosial peserta didik mengalami peningkatan dari siklus I ke siklus II. Berikut tabel yang mendeskripsikan hasil peningkatan perubahan sikap sosial peserta didik dalam pembelajaran membaca teks klasifikasi menggunakan metode SQ3R dengan media gambar.

Tabel 3 Peningkatan Perubahan Sikap Sosial pada Siklus I dan Siklus II

\begin{tabular}{|c|c|c|c|c|}
\hline $\begin{array}{l}\mathrm{N} \\
\mathrm{o} .\end{array}$ & $\begin{array}{l}\text { Aspek } \\
\text { Observasi }\end{array}$ & $\begin{array}{l}\text { Sikl } \\
\text { us I }\end{array}$ & $\begin{array}{l}\text { Sikl } \\
\text { us II }\end{array}$ & $\begin{array}{l}\text { Peningkat } \\
\text { an } \\
\text { Pencapai } \\
\text { an }\end{array}$ \\
\hline 1. & Jujur & $\begin{array}{l}100 \\
\%\end{array}$ & $\begin{array}{l}100 \\
\%\end{array}$ & $0 \%$ \\
\hline 2. & $\begin{array}{l}\text { Tanggung } \\
\text { jawab }\end{array}$ & $\begin{array}{l}100 \\
\%\end{array}$ & $\begin{array}{l}100 \\
\%\end{array}$ & $0 \%$ \\
\hline 3. & Toleransi & $\begin{array}{l}100 \\
\%\end{array}$ & $\begin{array}{l}100 \\
\%\end{array}$ & $0 \%$ \\
\hline 4. & Santun & $\begin{array}{l}100 \\
\%\end{array}$ & $\begin{array}{l}100 \\
\%\end{array}$ & $0 \%$ \\
\hline 5. & Percaya diri & $17 \%$ & $88 \%$ & $71 \%$ \\
\hline 6. & Kritis & $17 \%$ & $83 \%$ & $66 \%$ \\
\hline 7. & $\begin{array}{l}\text { Kepemimpi } \\
\text { nan }\end{array}$ & $13 \%$ & $83 \%$ & $70 \%$ \\
\hline 8. & Semangat & $\begin{array}{l}100 \\
\%\end{array}$ & $\begin{array}{l}100 \\
\%\end{array}$ & $0 \%$ \\
\hline
\end{tabular}

Pengetahuan membaca teks klasifikasi peserta didik kelas X-2 SMA Taruna Nusantara Magelang mengalami peningkatan dan dapat memenuhi target ketuntasan yang diharapkan. 
Pada siklus I, nilai rata-rata tes pengetahuan mencapai 95 dengan ketuntasan $96 \%$. Sementara pada siklus II nilai rata-rata meningkat menjadi 98 dengan ketuntasan 100\%. Dengan demikian, terjadi peningkatan $4 \%$ dalam penilaian pengetahuan membaca teks klasifikasi peserta didik dari siklus I ke siklus II. Hasil tes pengetahuan dapat dilihat pada tabel berikut.

Tabel 4 Hasil Tes Pengetahuan Membaca Teks Klasifikasi Siklus I dan II

\begin{tabular}{|c|c|c|c|c|c|c|c|}
\hline \multirow[t]{2}{*}{ No } & \multirow[t]{2}{*}{ Skor } & \multicolumn{3}{|c|}{ Siklus I } & \multicolumn{3}{|c|}{ Siklus II } \\
\hline & & $\mathrm{F}$ & $\mathrm{P}$ & $B$ & $\mathrm{~F}$ & $\mathrm{P}$ & B \\
\hline \multirow[t]{4}{*}{1.} & 100 & 1 & 7 & 1 & 2 & 9 & 22 \\
\hline & & 8 & 8 & 8 & 2 & 2 & 00 \\
\hline & & & $\%$ & 0 & & $\%$ & \\
\hline & & & & 0 & & & \\
\hline \multirow[t]{3}{*}{2.} & 80 & 4 & 1 & 3 & 2 & 8 & 16 \\
\hline & & & 7 & 2 & & $\%$ & 0 \\
\hline & & & $\%$ & 0 & & & \\
\hline \multirow[t]{2}{*}{3.} & 60 & 1 & 4 & 6 & 0 & 0 & 0 \\
\hline & & & $\%$ & 0 & & $\%$ & \\
\hline \multirow[t]{2}{*}{4.} & 40 & 0 & 0 & 0 & 0 & 0 & 0 \\
\hline & & & $\%$ & & & $\%$ & \\
\hline \multirow[t]{2}{*}{5.} & $0-20$ & 0 & 0 & 0 & 0 & 0 & 0 \\
\hline & & & $\%$ & & & $\%$ & \\
\hline \multicolumn{2}{|c|}{ Jumlah } & 2 & 1 & 2 & 2 & 1 & 23 \\
\hline & & 3 & 0 & 1 & 4 & 0 & 60 \\
\hline & & & & 8 & & 0 & \\
\hline & & & $\%$ & 0 & & $\%$ & \\
\hline \multirow{2}{*}{\multicolumn{2}{|c|}{ Rata-rata }} & \multirow{2}{*}{\multicolumn{3}{|c|}{$\frac{2180}{23}=95$}} & \multirow{2}{*}{\multicolumn{3}{|c|}{$\frac{2360}{24}=98$}} \\
\hline & & & & & & & \\
\hline \multicolumn{2}{|c|}{ Ketuntasan } & \multirow{3}{*}{\multicolumn{3}{|c|}{$\begin{array}{l}\underline{22} \times 100 \% \\
=96 \% \\
23 \\
\text { (Tuntas) }\end{array}$}} & \multirow{3}{*}{\multicolumn{3}{|c|}{$\begin{array}{l}\frac{24}{100 \%} \times 100 \%= \\
24 \\
\text { (Tuntas) }\end{array}$}} \\
\hline & & & & & & & \\
\hline & & & & & & & \\
\hline \multicolumn{8}{|c|}{ Keterangan: } \\
\hline $\mathrm{F}$ & \multicolumn{7}{|c|}{$=$ Frekuensi } \\
\hline$P$ & \multicolumn{7}{|c|}{$=$ Persentase } \\
\hline B & \multicolumn{7}{|c|}{$=$ Bobot $/$ jumlah skor } \\
\hline
\end{tabular}

Selain pengetahuan, keterampilan membaca teks klasifikasi peserta didik kelas X-2 SMA Taruna Nusantara Magelang mengalami peningkatan setelah mengikuti pembelajaran membaca teks klasifikasi menggunakan metode SQ3R dengan media gambar. Pada siklus I, nilai rata-rata penilaian keterampilan mencapai 82 dengan persentase ketuntasan $57 \%$. Sementara pada siklus II nilai rata-rata meningkat signifikan

\begin{tabular}{|c|c|c|c|c|c|c|c|}
\hline \multirow[t]{2}{*}{ No } & \multirow[t]{2}{*}{ Skor } & \multicolumn{3}{|c|}{ Siklus I } & \multicolumn{3}{|c|}{ Siklus II } \\
\hline & & $\mathrm{F}$ & $\mathrm{P}$ & B & $\mathrm{F}$ & $\mathrm{P}$ & B \\
\hline \multirow[t]{2}{*}{1.} & $90-100$ & 5 & 22 & 47 & 21 & 88 & 19 \\
\hline & & & $\%$ & 0 & & $\%$ & 65 \\
\hline \multirow[t]{2}{*}{2.} & $70-85$ & 16 & 70 & 12 & 3 & 12 & 25 \\
\hline & & & $\%$ & 85 & & $\%$ & 5 \\
\hline \multirow[t]{2}{*}{3.} & $50-65$ & 2 & 9 & 12 & 0 & 0 & 0 \\
\hline & & & $\%$ & 5 & & $\%$ & \\
\hline \multirow[t]{2}{*}{4.} & $25-45$ & 0 & 0 & 0 & 0 & 0 & 0 \\
\hline & & & $\%$ & & & $\%$ & \\
\hline \multirow[t]{2}{*}{5.} & $0-20$ & 0 & 0 & 0 & 0 & 0 & 0 \\
\hline & & & $\%$ & & & $\%$ & \\
\hline \multirow{3}{*}{\multicolumn{2}{|c|}{ Jumlah }} & 23 & 10 & 18 & 24 & 10 & 22 \\
\hline & & & 0 & 80 & & 0 & 20 \\
\hline & & & $\%$ & & & $\%$ & \\
\hline \multicolumn{2}{|c|}{ Rata-rata } & \multicolumn{3}{|c|}{$\frac{1880}{23}=82$} & \multicolumn{3}{|c|}{$\frac{2220}{24}=93$} \\
\hline \multirow{3}{*}{\multicolumn{2}{|c|}{ Ketuntasan }} & \multicolumn{3}{|c|}{$13 \times 100 \%$} & \multicolumn{3}{|c|}{$24 \times 100 \%=$} \\
\hline & & \multicolumn{3}{|c|}{23} & \multicolumn{3}{|c|}{24} \\
\hline & & \multicolumn{3}{|c|}{ (Tuntas) } & \multicolumn{3}{|c|}{ (Tuntas) } \\
\hline
\end{tabular}

menjadi 93. Persentase ketuntasan pada siklus II juga meningkat secara tajam menjadi $100 \%$. Dengan demikian, keterampilan peserta didik mengalami peningkatan dari siklus I ke siklus II. Berikut tabel yang mendeskripsikan peningkatan hasil tes keterampilan membaca teks klasifikasi menggunakan metode SQ3R dengan media gambar pada peserta didik kelas X-2 SMA Taruna Nusantara Magelang.

Tabel 5 Hasil Tes Keterampilan Membaca Teks Klasifikasi Siklus I dan II

Keterangan:

$$
\begin{array}{ll}
\mathrm{F} & =\text { Frekuensi } \\
\mathrm{P} & =\text { Persentase } \\
\mathrm{B} & =\text { Bobot/jumlah skor }
\end{array}
$$

Tanggapan peserta didik terhadap pembelajaran membaca teks klasifikasi menggunakan metode SQ3R dengan media gambar sangat baik. Berdasarkan hasil jurnal dan wawancara, peserta didik tampak puas dengan pembelajaran ini. Mereka merasakan kemudahan, kenyamanan, dan keberhasilan 
dalam pembelajaran membaca teks klasifikasi menggunakan metode SQ3R dengan media gambar. Kesan peserta didik pada pembelajaran ini dari siklus I dan siklus II juga sangat positif. Dengan demikian, pembelajaran membaca teks klasifikasi menggunakan metode SQ3R dengan media gambar dapat diterima secara positif oleh peserta didik kelas X-2 SMA Taruna Nusantara Magelang.

Tanggapan guru sebagai kolaborator terhadap pembelajaran membaca teks klasifikasi menggunakan metode SQ3R dengan media gambar sangat baik. Hasil jurnal guru menunjukkan respon positif dari guru sebagai kolaborator dalam penelitian ini. Guru menilai penelitian ini berhasil. Menurut guru juga tampak perbandingan yang positif antara siklus I dan siklus II. Peserta didik yang semula masih bingung dengan metode baru dalam pembelajaran, mulai aktif, kondusif, dan interaktif dalam siklus II. Berdasarkan hasil jurnal guru, guru tampak mendukung dan senang dengan penelitian ini. Dengan demikian, pembelajaran membaca teks klasifikasi menggunakan metode SQ3R dengan media gambar mendapatkan respon positif dari guru mata pelajaran bahasa Indonesia pada kelas X-2 SMA Taruna Nusantara Magelang.

\section{PENUTUP}

Simpulan

Berdasarkan data, analisis, dan pembahasan dalam penelitian ini yang telah diuraikan pada bagian sebelumnya, penulis mengambil simpulan sebagai berikut.

1) Keberlangsungan proses pembelajaran membaca teks klasifikasi pada peserta didik kelas

X-2 SMA Taruna Nusantara Magelang semakin baik. Pada siklus I aspek pengamatan proses mengalami masih belum maksimal. Namun, pada siklus II setiap aspek pengamatan proses mengalami peningkatan. Rata-rata peningkatan persentase ketuntasan hasil pengamatan proses pembelajaran dari siklus I ke siklus II meningkat $13 \%$.
2) Sikap religius peserta didik kelas $X-2$ SMA Taruna Nusantara Magelang mengalami peningkatan setelah mengikuti pembelajaran membaca teks klasifikasi menggunakan metode SQ3R dengan media gambar. Pada siklus I, persentase ketuntasan sikap religius peserta didik mencapai $83 \%$. Sementara pada siklus I, persentase ketuntasan sikap religius peserta didik meningkat menjadi 92\%. Dengan demikian, sikap religius peserta didik mengalami peningkatan $9 \%$ dari siklus I ke siklus II.

3) Sikap sosial peserta didik kelas X-2 SMA Taruna Nusantara Magelang mengalami peningkatan setelah mengikuti pembelajaran membaca teks klasifikasi menggunakan metode SQ3R dengan media gambar. Pada siklus I, sikap jujur, tanggung jawab, toleransi, santun, dan semangat melampaui ketuntasan dengan persentase ketuntasan 100\%. Sementara sikap percaya diri dan kritis mencapai persentase ketuntasan yang masih lemah, yaitu $17 \%$. Adapun sikap kepemimpinan menjadi sikap yang berada pada persentase ketuntasan terendah sebesar $13 \%$. Namun, pada siklus II sikap sosial peserta didik mengalami peningkatan. Sikap jujur, tanggung jawab, toleransi, santun, dan semangat masih pada persentase ketuntasan $100 \%$. Sikap percaya diri mengalami peningkatan sebesar $71 \%$ dengan persentase ketuntasan $88 \%$ pada siklus II. Sikap kritis meningkat $66 \%$ dengan persentase ketuntasan $83 \%$ pada siklus II. Adapun sikap kepemimpinan meningkat 70\% dengan persentase ketuntasan $83 \%$ pada siklus II. Dengan demikian, sikap sosial peserta didik mengalami peningkatan dari siklus I ke siklus II.

4) Pengetahuan membaca teks klasifikasi peserta didik kelas X-2 SMA Taruna Nusantara Magelang mengalami peningkatan dan dapat memenuhi target ketuntasan yang diharapkan. Pada siklus I, nilai rata-rata tes pengetahuan mencapai 95 dengan ketuntasan 96\%. Sementara pada siklus II nilai rata-rata meningkat menjadi 98 dengan ketuntasan 100\%. Dengan demikian, terjadi peningkatan $4 \%$ dalam penilaian pengetahuan membaca teks klasifikasi peserta didik dari siklus I ke siklus II.

5) Keterampilan membaca teks klasifikasi peserta didik kelas X-2 SMA Taruna Nusantara 
Magelang mengalami peningkatan setelah mengikuti pembelajaran membaca teks klasifikasi menggunakan metode SQ3R dengan media gambar. Pada siklus I, nilai rata-rata penilaian keterampilan mencapai 82 dengan persentase ketuntasan 57\%. Sementara pada siklus II nilai rata-rata meningkat signifikan menjadi 93. Persentase ketuntasan pada siklus II juga meningkat secara tajam menjadi $100 \%$.

\section{Saran}

Berdasarkan simpulan tersebut, peneliti merekomendasikan saran sebagai berikut.

1) Guru mata pelajaran bahasa Indonesia hendaknya menggunakan metode SQ3R dan media gambar dalam pembelajaran membaca. Pembelajaran membaca teks klasifikasi menggunakan metode SQ3R dengan media gambar dapat menjadi alternatif dalam pembelajaran membaca. Sebab, metode SQ3R dan media pembelajaran dapat memudahkan serta memotivasi peserta didik dalam pembelajaran membaca teks klasifikasi.

2) Penerapan metode SQ3R dengan media gambar diharapkan dapat digunakan sebagai masukan peneliti lain dalam melakukan penelitian yang serupa. Penelitian ini juga dapat digunakan sebagai bahan perbandingan pembelajaran atau penelitian lain, sehingga dapat diketahui hasil yang efektif dalam penggunaan metode serta media dalam pembelajaran membaca.

\section{DAFTAR PUSTAKA}

Abidin, Yunus. 2012. Pembelajaran Bahasa Berbasis Pendidikan Karakter. Bandung: Refika Aditama.

Basrowi, H.M dan Suwandi. 2008. Prosedur Penelitian Tindakan Kelas. Bogor: Ghalia Indonesia.

Carlston, David. 2012. "Benefits of Student Generated Note Packets: A Preliminary Investigation of SQ3R Implementation" Midwestern State University. Volume 9 Number 12. Hal. 31.

Haryadi. 2010. Retorika Membaca: Model, Metode, dan Teknik. Semarang: Rumah Indonesia.

Kasson, Sarah C. 2012. "Which Study Method Works Best? A Comparison of SOAR and SQ3R for
Text Learning" University of Nebraska. Volume 12 Number 1. Hal. 165.

Kosasih, Engkos. 2013. Cerdas Berbahasa Indonesia Untuk SMA/MA Kelas X. Jakarta: Erlangga. Maryanto dkk. 2013. Buku Guru Bahasa Indonesia Ekspresi Diri dan Akademik. Jakarta: Kementrian Pendidikan dan Kebudayaan Republik Indonesia.

Maryanto dkk. 2013. Buku Siswa Bahasa Indonesia Ekspresi Diri dan Akademik. Jakarta: Kementrian Pendidikan dan Kebudayaan Republik Indonesia.

Nurhadi. 2005. Bagaimana Meningkatkan Kemampuan Membaca? Bandung: Sinar Baru Algesindo.

Rahim, Farida. 2008. Pengajaran Membaca di Sekolah Dasar. Jakarta: Bumi Aksara.

Sadiman, Arief. 1990. Media Pendidikan: Pengertian, Pengembangan, dan Pemanfaatan. Jakarta: Rajawali.

Suharto, S. (1997). Musik dan Bahasa. Medi FBS Ikip Semarang, 20(4), 286-393.

Wulan, Ratna. 2010. "The Role Of Intelligence, Vocabulary Knowledge, Attitudes, and Interest on Children's Reading Comprehension" Jurnal Penelitian dan Evaluasi Pembelajaran. Volume 14 Nomor 2. Hal. 166-185.

Metode Menulis Berantai pada Siswa Sekolah Menengah Atas". BASASTRA Jurnal Penelitian Bahasa, Sastra Indonesia dan Pengajarannya Volume 1 Nomor 1, April 2012, ISSN I2302-6405.

http://bastind.fkip.uns.ac.id/wpcontent/uploads/2013/02/Tri-Wulandari. Diunduh pada Kamis, 16 Oktober 2014 pukul 18.02 WIB. 